\title{
FEeding SeleCtivity of Montane AND LONG-TAILED VOLES (MICROTUS MONTANUS AND M. LONGICAUDUS)
}

\author{
FREDERICK J. JANNETT, JR. DEPARTMENT OF BIOLOGY \\ THE SCIENCE MUSEUM OF MINNESOTA $\bullet$ ST. PAUL
}

\section{$\checkmark$ OBJECTIVES}

The purpose of the research begun in 1989 is to ascertain how selectively these species feed, and to assess vegetation as a factor in demographic processes in the two species. Microtus longicaudus exhibits relatively stable numbers while $M$. montanus has dramatic fluctuations in some habitats. The study sites for M. montanus have been chosen to include primary and secondary habitat, and proximate and isolated habitat patches. Vegetation has heretofore not been quantitatively analyzed.

\section{$\checkmark \quad$ METHODS}

Virtually all previous work on these species by the author (1971-1977, 1982-1988) involved live trapping. The work of interest requires specimens obtained in Museum Special traps for stomach content analysis. The trapping begun in 1989 is a preliminary effort, the first purpose of which was to assess the efficacy of Museum Special traps. The number of sites where $M$. longicaudus is found is being increased across a spectrum of vegetation types. Only three populations of this species were monitored from 1982-1988. Also, at three sites with populations of $M$. montanus, live traps are still deployed to secure voles. It is hoped that, by replicating previous efforts at these three sites, work on food habits can be related to possible changes in vole numbers. For this end the three sites chosen for continued monitoring with live traps were one site having definite population fluctuations, one site peripheral to primary habitat, and one site of secondary habitat.

Most trapping periods were limited to two days so that impact on the respective populations would be minimized. From fresh specimens, eyes were removed for age determination upon lens weight (Gourley and Jannett, 1975).

Tissues from specimens of heather voles (Phenacomys intermedius) were prepared for another researcher's DNA-DNA recombination research.

\section{$\checkmark \quad$ RESULTS}

At two sites the populations of $M$. montanus increased from October, 1990 to October, 1991 by factors of 1.4 and 1.9, respectively. But in secondary habitat, the numbers of voles merely increased from 2 to 4 .

Breeding had ceased in all three populations of M. montanus by October. Of 22 apparently parous females, only one was still lactating and none were pregnant, nor were there any first pregnancy females. The sex ratios (males:females) of reproductively active and formerly reproductively active individuals 
in the two high density populations were $1: 2.3$ and $1: 1.6$, respectively.

Time and weather permitted the worker to find only three additional $M$. longicaudus sites. Tissues were obtained from a small series of specimens suspected to be $P$. intermedius secured incidental to the other work.

\section{- DISCUSSION}

Eighteen populations of $M$. montanus were previously identified 1982-1988, but only nine of $M$. longicaudus have been "found" to date. I will identify 18 preliminary to vegetation and gut analyses.

The pattern of early cessation of seasonal breeding in high density populations of $M$. montanus (Jannett, 1978) has again been observed. Continued monitoring of the three representative $M$. montanus sites is showing the disparity in population size trends within one year. Whether there is concomitant disparity in morphological patterns among specimens awaits processing and analyses.

\section{$\checkmark \quad$ ACKNOWLEDGEMENTS}

I thank the National Park Service for permission to work in Grand Teton National Park, and the University of Wyoming-National Park Service Research Center for its hospitality. This work was supported by the Science Museum of Minnesota.

\section{- LITERATURE CITED}

Gourley, R. S. and F. J. Jannett, Jr. 1975. Pine and montane vole age estimates from eye lens weights. J. Wildl. Manage., 39: 550-556.

Jannett, F. J., Jr. 1978. The density-dependent formation of extended maternal families of the montane vole, Microtus montanus nanus. Behav. Ecol. Sociobiol., 3: 245-263. 